\title{
Article \\ Energy Efficiency of Inland Waterways Transport for Agriculture: The Ukraine Case Study
}

\author{
Oleg Bazaluk ${ }^{1}\left(\mathbb{D}\right.$, Valerii Havrysh ${ }^{2} \mathbb{D}$ and Vitalii Nitsenko ${ }^{3,4,5, *(\mathbb{C})}$ \\ 1 Belt and Road Initiative Institute for Chinese-European Studies, Guangdong University of Petrochemical \\ Technology, Maoming 525000, China; bazaluk@ukr.net \\ 2 Department of Tractors and Agricultural Machinery, Operating and Maintenance, Mykolayiv National \\ Agrarian University, 54020 Mykolaiv, Ukraine; havryshvi@mnau.edu.ua \\ 3 Department of Entrepreneurship and Marketing, Ivano-Frankivsk National Technical Oil and Gas University, \\ 76000 Ivano-Frankivsk, Ukraine \\ 4 Department of Economics and Finance, Odesa National Maritime University, 65029 Odesa, Ukraine \\ 5 SCIRE Foundation, 00867 Warsaw, Poland \\ * Correspondence: vitaliinitsenko@onu.edu.ua; Tel.: +380-93-998-30-73
}

Citation: Bazaluk, O.; Havrysh, V.; Nitsenko, V. Energy Efficiency of Inland Waterways Transport for Agriculture: The Ukraine Case Study. Appl. Sci. 2021, 11, 8937. https:// doi.org/10.3390/app11198937

Academic Editors: Piera Centobelli and José A. Orosa

Received: 19 August 2021

Accepted: 21 September 2021

Published: 25 September 2021

Publisher's Note: MDPI stays neutra with regard to jurisdictional claims in published maps and institutional affiliations.

Copyright: (c) 2021 by the authors. Licensee MDPI, Basel, Switzerland. This article is an open access article distributed under the terms and conditions of the Creative Commons Attribution (CC BY) license (https:// creativecommons.org/licenses/by/ $4.0 /)$.

\begin{abstract}
In Ukraine, there has been an increase in agricultural production. The availability of river basins and seaports contributes to the use of inland shipping. However, there is a lack of understanding of how to reduce the energy consumption of inland shipping. We assume the hypothesis that the energy efficiency of inland shipping is much higher than it is technically possible. The purpose of this study is to identify perspective energy-saving technologies for IWT. We use statistical information to determine the export potential and to reveal the status of inland navigation. Traction efficiency, theoretical and actual specific fuel consumption were used as indicators to determine the energy efficiency. The main results are as follows. We have found the grain and sunflower seed production in the Dnieper Basin (Ukraine). Their shares range from 34.75 to $50.92 \%$ of national production. Therefore, there is a significant flow of products for inland shipping. The present status of inland waterways transport has been analyzed. The main novelty of this study is the finding of actual and theoretical technical specific energy consumption. It is revealed that actual specific energy consumption is five times higher compared to the theoretical one. Self-propelled vessels are inferior in energy efficiency to towing barges. The energy efficiency of inland waterways transport has been compared to railways and road freight transport. Transport management was identified as the more effective tool to improve the energy efficiency of inland shipping.
\end{abstract}

Keywords: grain; transportation; seaports; barge; efficiency; energy; inland shipping

\section{Introduction}

The Government of Ukraine has developed some programs to increase the production of grain. The first program was developed in 1998. It set a goal to reach 50 million tons by 2005 [1]. According to The Grain of Ukraine Program-2015, Ukrainian farmers are expected to harvest 80 million tons by 2017. Some experts estimate the grain potential up to 100 million tons [2]. Moreover, Ukraine is ranked first in sunflower oil production. Since 2008 Ukraine has harvested more than 50 million tons [3,4]. At the same time, domestic consumption does not exceed 27 million tons per year. Thus, the country has significant export potential. To implement this potential, it is necessary to create appropriate conditions, including a developed export infrastructure. Furthermore, transport is its integral part.

A significant share of agricultural crop products is exported, which requires transportation from the fields to seaports. Oversea shipping provides trade in agricultural products between countries and continents. The international seaborne trade has been increasing over the last decades. Further, one of its important problems is the determining 
of optimal serviced ports [5]. The coordination between inland transportation and maritime transportation is considered by Qi et al. [6]. They showed that the optimal ship schedule depends on cargo arrival patterns, storage cost, and the bunker price.

To hold competitive positions and avoid financial losses, shipping companies have to improve the efficiency of their vessel schedules. The vessel scheduling problem was studied by Dulebenets [7]. His results demonstrate that optimization between shipping companies and terminal operators may significantly reduce the production costs of transportation. Vessel schedules are found to be sensitive to fuel prices.

The current practice confirms the advisability to deploy a combination of ships of different types with different carrying capacities (a so-called heterogeneous fleet). It is a common practice for the shipment of agricultural products. Wand et al. [8] studied scheduling problems for a fleet of heterogeneous vessels in a shipping route. They found that a heterogeneous fleet can reduce the total cost by $5 \%$ compared to a homogeneous fleet. However, heterogeneous fleets have been investigated by very few studies [9].

There are some transportation modes such as roads, railways, and inland waterway transport (IWT). This transportation is currently carried out mainly by trucks. This fact leads to increased energy consumption, cost, and reduced profitability [10]. Growth of transportation increases in harmful impacts on the environment. Road transport is the most polluting one. Harmful emissions cause external costs, and consumers must cover them. Therefore, there is a problem in reducing energy consumption, harmful emissions, and the cost of transport operations. To solve the above problems, inland waterways transport should be used [11,12]. This transportation mode is low-cost and environmentally friendly [11,12].

Connecting seaports with agricultural producers using IWT infrastructure may become a competitive advantage for farmers and ports [13]. The sustainable development of seaports and IWT infrastructure are important elements of economic policy [14].

\section{Literature Review}

Many scientists have studied the problems of reducing energy consumption and operating costs of products transportation. The inland waterway transport is a spotlight of many studies. Biswas was a pioneer in studying the use of IWT for the transportation of agricultural products [15]. Ivanchenko et al. [16] analyzed the regulation of curbing harmful emissions for river and sea vessels which depend on energy efficiency too. Yerofeev V.L. and Yerofeeva E.V. [17] considered the prospects of improving energy efficiency. Furfari [18] studied the energy efficiency of engines for transport. There are scientific works devoted to the assessment of the use of different types of fuels, including alternative ones [19-21]. It is noteworthy that agricultural residues can be used as an energy resource [22]. Song et al. [23] investigated energy consumption and energy efficiency of the transportation sector in Shanghai. Van Lier and Macharis [24] recommended applying a life-cycle analysis (LCA) to assess the environmental impact of IWT. Jonkeren et al. [25] presented a tool that can be used to evaluate how IWT contributes to energy and carbon dioxide saving. The NAIADES (Navigation and Inland Waterway Action and Development in Europe) action program aims at enhancing the quality of IWT. The further integration of IWT in the supply chains studied by Caris et al. [26]. A concept of freight trains for the Dnieper, Black Sea, and the Danube has been developed [27]. The historical stages and problems of the inland waterways transport in Ukraine have been analyzed by Pidlisnyi [28].

IWT is a link in the export transport chain of agricultural products: agricultural production $\rightarrow$ road transport $\rightarrow$ IWT $\rightarrow$ maritime transportation $\rightarrow$ consumers. Its energy efficiency directly affects the cost of transportation and, consequently, the competitiveness of farmers. However, at present, more attention is paid to economic indicators, and the energy component has not been studied enough. Currently, there is a lack of studies devoted to comparing the actual and theoretically possible energy efficiency of IWT. This information is of importance for the correct identification of promising energy-saving technologies. Some issues of determining innovative ways to reduce the energy intensity of product 
transportation need further research. We have put forward a hypothesis that the energy efficiency of IWT is far apart from a technically possible value. The novelty of this study is the evaluation of the difference between the actual and technically achievable energy efficiency and, on this base, the choosing prospect ways to improve this energy indicator.

Therefore, the purpose of this study is to determine energy efficiency of IWT and to identify perspective energy-saving technologies for IWT. Objectives are as follows: to determine the export potential of agricultural products (grain and sunflower oil) in the Dnieper Basin; to analyze the energy efficiency of inland waterway transportation (potential and actual); to reveal the prospective way for energy saving.

\section{Materials and Methods}

According to Yin [29], this case study research includes the formulation of a hypothesis, the collection of necessary data, its analysis, and the drawing of conclusions. Thus, a case study comprises four steps (Figure 1). A flowchart identifying the different stages in the research methodology is presented in Figure 2.

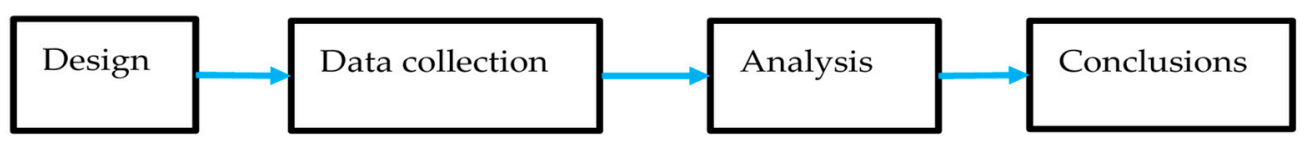

Figure 1. Steps of a case study.

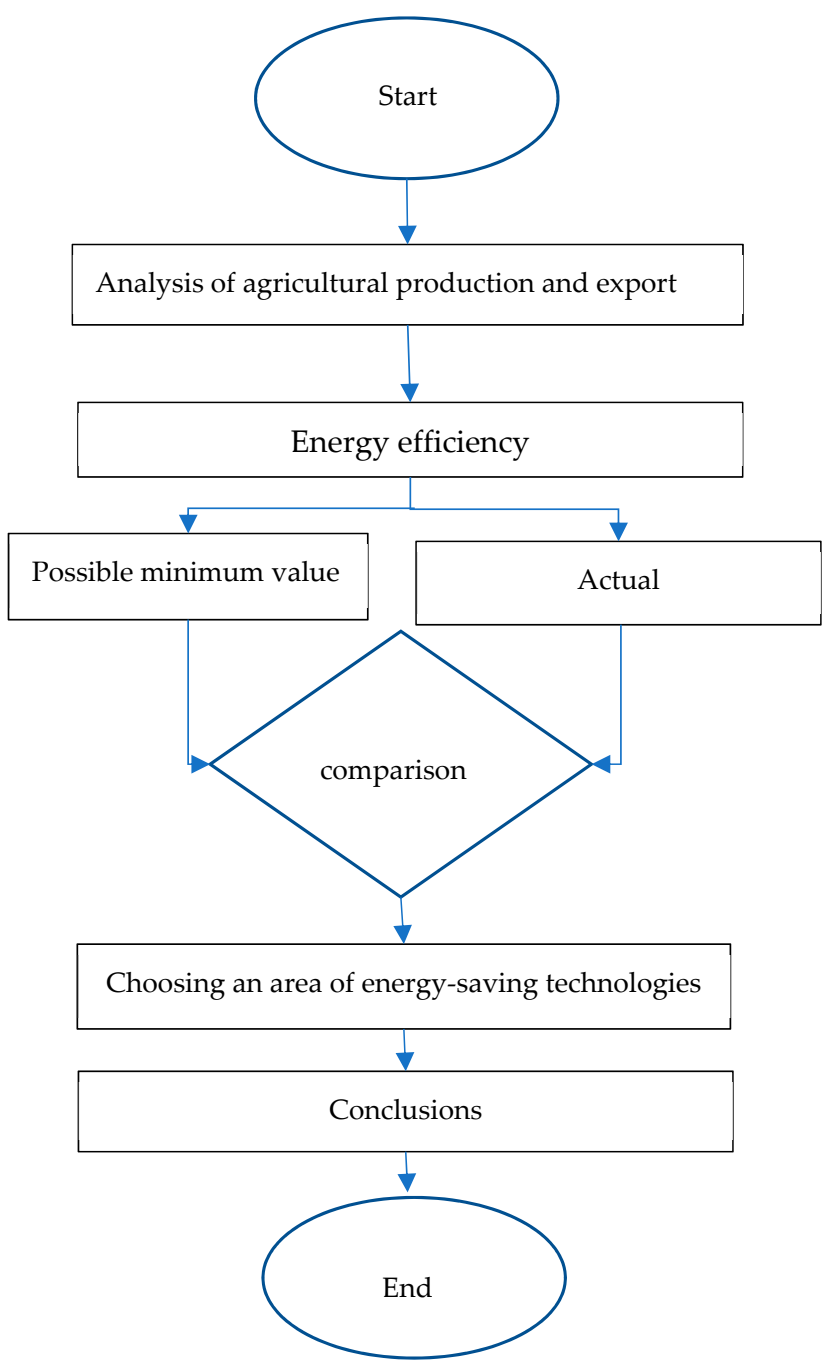

Figure 2. Flowchart of the research methodology. 
To achieve the purpose of this study, the research field has to be determined. Different foci such as geographical, temporal, material, and modal are considered. Geographically (where?), we focus on the area along the Dnieper Basin. This is the main waterway of Ukraine. The temporal focus looks for an answer to the question "when?". The IWT is outlined up to its current state. We also focus on the future. As to the material focus, we investigate the energy efficiency of IWT. Further, and finally the modal focus (How?)-we use a number of indicators such as traction efficiency, specific energy consumption, actual energy consumption.

This study begins by identifying the export potential of the regions that are located in the Dnieper Basin. This step is necessary to determine the volume of shipments to seaports, and consequently, the potential volume of inland waterways transportation. That is why the market potential for inland shipping for the Dnieper basin is estimated. We used official statistical information to determine grain and sunflower seed production history, their export history. This information allows us to find the export potential of regions located in the Dnieper Basin. Based on statistical data, the current status of IWT as a transport facility for agricultural products is determined.

Energy efficiency is determined for road, railway, and IWT. To compare different kinds of transport, we used such indicators as specific energy consumption, traction efficiency, and actual specific energy consumption. Railway, road, and IWT specific energy consumption are combined with tkm data, allowing the calculation of energy intensities for freight activity. Data from the specification of transport means (self-propelled vessels, barges, tugs, and pushers) are taken to determine the energy indicators from the specification. To find actual energy consumption, statistical yearbooks are used (carriage of goods and consumption of fuels). When transport companies do not report any energy consumption, we calculated this indicator using technical data of transport facilities. Actual specific energy consumption is the total energy consumption to the carriage of goods:

$$
A E C=\sum_{i=1}^{n}\left(E C_{i}\right) \cdot O E \cdot A C G^{-1}, \mathrm{~kJ} / \mathrm{tkm}
$$

where $O E$ is the oil equivalent, $O E=41,800 \mathrm{~kJ} / \mathrm{kg}$; $A C G$ is the carriage of goods $\mathrm{tkm} ; E C_{i}$ is the fuel consumption of $i$ th kind, $\mathrm{kg}$ of oil equivalent.

Theoretical minimum specific energy consumption (loaded voyage) is:

$$
S E C T=L F \cdot R P \cdot b e \cdot L H V \cdot(L C \cdot v)^{-1}, \mathrm{~kJ} / \mathrm{tkm},
$$

where $L C$ is the cargo capacity, $\mathrm{t} ; L F$ is the load factor; $R P$ is the rated power, $\mathrm{kW}$; be is the specific fuel consumption, $\mathrm{kg} / \mathrm{kWh}$; $L H V$ is the lower heating value of fuel, $\mathrm{kJ} / \mathrm{kg}$; $v$ is the speed, $\mathrm{km} / \mathrm{h}$.

Traction efficiency can be found as cargo carried to a rated power ratio:

$$
C C P R=L C \cdot R P^{-1}, \mathrm{t} / \mathrm{kW} \text {. }
$$

\section{Results and Discussion}

\subsection{Grain and Sunflower Oil Export Potential}

Production of primary agricultural products (grain and sunflower seeds) is increasing. It results in growing their export (Figures 3 and 4) [3,4]. Ukraine is a significant player in the international market of agricultural products. In the 2019-2020 marketing year, Ukraine ranked first in sunflower oil imports and second in grain imports [30]. Asia, Africa, and Europe are major consumers of Ukrainian grain. In 2020, China and Egypt held top positions in the rating of the largest importers [31]. Most of the grain and sunflower oil are delivered to consumers by water transport. 


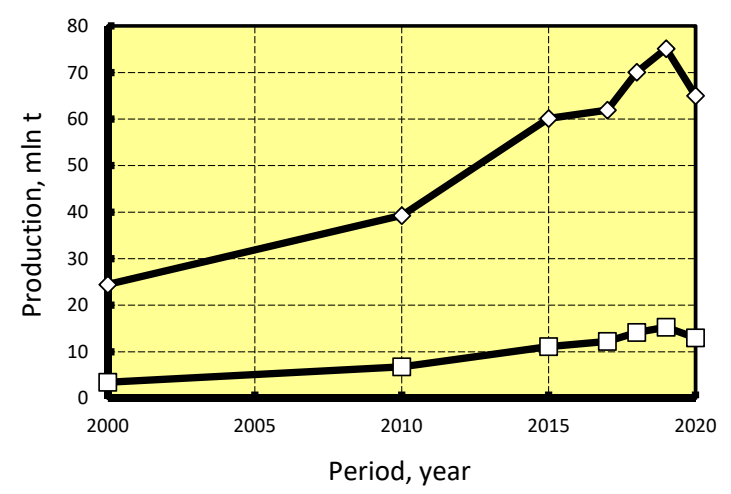

$\longrightarrow$ Grain and leguminous crops $\quad \square$ Sunflower seeds

Figure 3. Grain and sunflower seed production history.

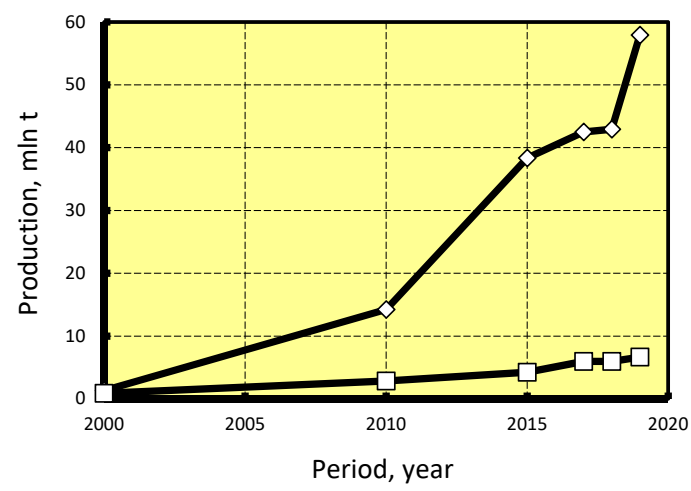

$\longrightarrow$ Grain and leguminous crops $\quad \square$ Sunflower oil

Figure 4. Grain and sunflower oil export history.

Cherkasy, Dnipropetrovsk, Kyiv, Kherson, Mykolaiv, Poltava, and Zaporizhzhya regions are located in the Dnieper Basin. They produce a significant value of the above products (Table 1) [3,4]. Their share is within the range: grain and leguminous crops from 34.75 to $40.03 \%$; sunflower seeds from 40.47 to $50.92 \%$. They can be transported by inland waterways transport. These regions are favorable for export of agricultural products. The export of grain and sunflower oil may exceed 60 million tons (Figure 1). Thus, the export potential of the above regions reaches around 35 million tons (Table 1).

Table 1. Modal split of agricultural products, million $\mathrm{t}$.

\begin{tabular}{lcccccccccccc}
\hline \multicolumn{1}{c}{ Item } & $\mathbf{2 0 0 0}$ & $\mathbf{2 0 1 0}$ & $\mathbf{2 0 1 5}$ & $\mathbf{2 0 1 7}$ & $\mathbf{2 0 1 8}$ & $\mathbf{2 0 1 9}$ & $\mathbf{2 0 0 0}$ & $\mathbf{2 0 1 0}$ & $\mathbf{2 0 1 5}$ & $\mathbf{2 0 1 7}$ & $\mathbf{2 0 1 8}$ & $\mathbf{2 0 1 9}$ \\
\hline \multicolumn{9}{c}{ Grain and Leguminous Crops } \\
\hline Ukraine & 24.46 & 39.27 & 60.13 & 61.92 & 70.06 & 75.14 & 3.46 & 6.77 & 11.12 & 12.24 & 14.17 & 15.25 \\
Regions & & & & & & & & & & & \\
Dnipropetrovsk & 1.57 & 2.71 & 3.87 & 3.58 & 3.49 & 4.29 & 0.45 & 0.86 & 1.20 & 1.20 & 1.28 & 1.45 \\
Zaporizhzhya & 1.15 & 1.91 & 2.73 & 2.91 & 2.23 & 3.34 & 0.44 & 0.76 & 0.96 & 0.87 & 0.72 & 1.02 \\
Kyiv & 1.43 & 2.00 & 2.82 & 2.65 & 4.08 & 4.22 & 0.03 & 0.12 & 0.29 & 0.40 & 0.51 & 0.51 \\
Mykolaiv & 0.92 & 2.20 & 2.90 & 2.67 & 2.67 & 3.14 & 0.25 & 0.59 & 0.94 & 0.88 & 1.09 & 1.06 \\
Poltava & 1.41 & 2.86 & 5.36 & 4.24 & 6.34 & 6.12 & 0.20 & 0.47 & 0.85 & 0.73 & 0.94 & 0.98 \\
Kherson & 1.12 & 1.51 & 2.62 & 2.55 & 2.27 & 2.74 & 0.15 & 0.36 & 0.49 & 0.50 & 0.55 & 0.64 \\
Cherkasy & 1.59 & 2.53 & 3.75 & 2.93 & 4.64 & 4.56 & 0.11 & 0.30 & 0.54 & 0.50 & 0.64 & 0.67 \\
Sum & $\mathbf{9 . 1 9}$ & $\mathbf{1 5 . 7 2}$ & $\mathbf{2 4 . 0 4}$ & $\mathbf{2 1 . 5 2}$ & $\mathbf{2 5 . 7 3}$ & $\mathbf{2 8 . 4 0}$ & $\mathbf{1 . 6 3}$ & $\mathbf{3 . 4 5}$ & $\mathbf{5 . 2 7}$ & $\mathbf{5 . 0 7}$ & $\mathbf{5 . 7 3}$ & $\mathbf{6 . 3 3}$ \\
Fraction, \% & 37.57 & 40.03 & 39.98 & 34.75 & 36.72 & 37.79 & 47.22 & 50.92 & 47.36 & 41.47 & 40.47 & 41.52 \\
\hline
\end{tabular}




\subsection{Inland Waterways Transportation: Present Status}

At present, railway transport is the most widely used. A significant part of the cargo is transported by road (Table 2) [32]. The principal reasons are economic problems. The cost structure of typical cabotage transportation under the Ukrainian flag includes, for example, the rent for the use of water resources. There are no such taxes in America or Europe. The excise tax on fuel is also taken into account. Today foreign fleet, which enters the internal territorial waters of Ukraine, does not pay the excise tax on fuel and purchases fuel cheaper than the Ukrainian fleet. At the same time, the Government of Ukraine has raised the fee for passing ships through locks and railway bridges by three times [33].

Table 2. Transportation of grain, million $\mathrm{t}$.

\begin{tabular}{lccccc}
\hline Transport & $\mathbf{2 0 1 5}$ & $\mathbf{2 0 1 6}$ & $\mathbf{2 0 1 7}$ & $\mathbf{2 0 1 8}$ & $\mathbf{2 0 1 9}$ \\
\hline Road & 14.71 & 15.74 & 17.61 & 16.70 & 24.37 \\
Railway & 29 & 32 & 37 & 34 & 40 \\
IWT & 0.561 & 0.491 & 0.377 & 0.419 & 0.461 \\
\hline
\end{tabular}

Large reserves of energy savings for transportation are the use of more economical inland waterway transport. The experience of many countries shows that the cost of water transport is almost four times cheaper than railway and road transport [10].

Some regions of Ukraine are located in the Dnieper Basin (Mykolaiv, Kherson, Dnipropetrovsk, Zaporizhzhya, Kyiv, Poltava, and Cherkasy). Mykolaiv and Kherson regions have access to the Black Sea and, accordingly, seaports. Moreover, Ukraine has access to the Danube River system (Odesa region). The use of waterways of the Dnieper transport hub will reduce the cost of logistics and unload highways. Inland shipping can carry a significant part of this export flow, which will reduce transport costs. However, IWT currently transports approximately 4 million tons (Figure 5) [34].

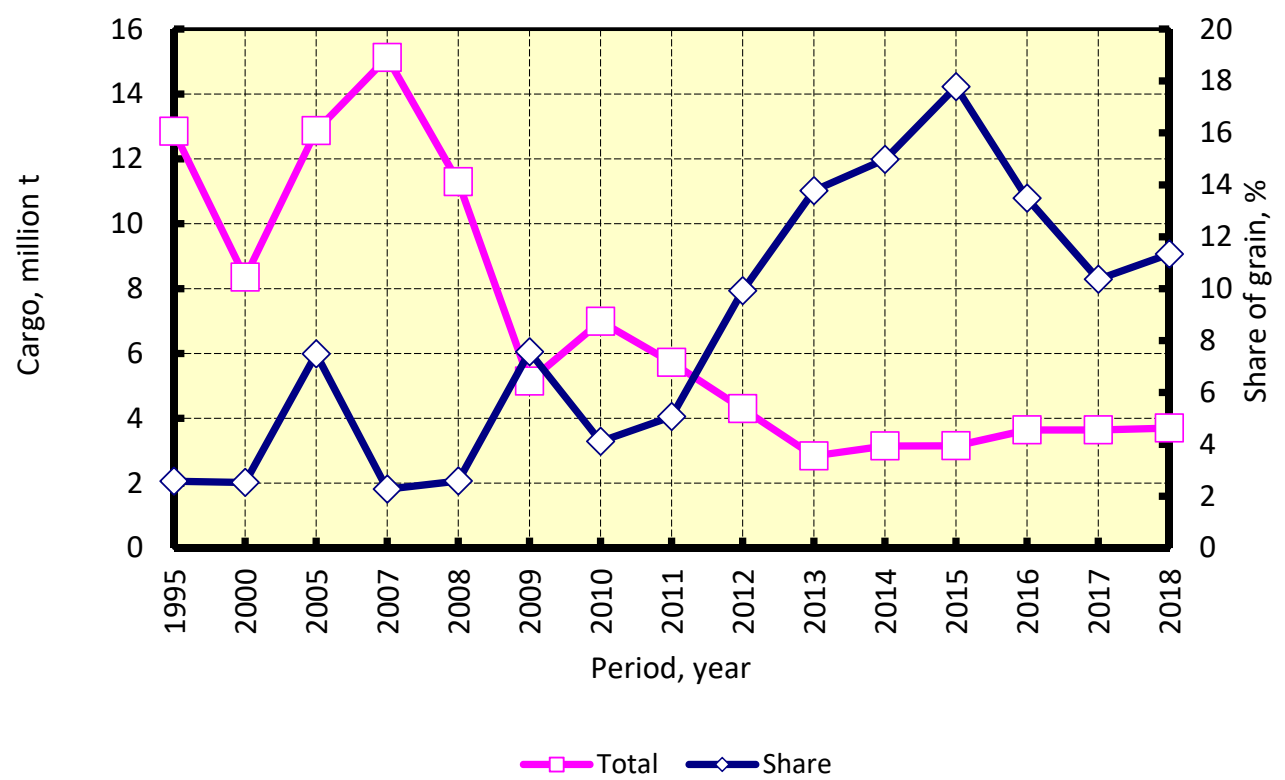

Figure 5. Cargo traffic by inland waterways transport in Ukraine.

For many years, no river dredging works have been carried out in Ukraine. Ukraine has obligations to the international community to maintain the depth along the waterway from the mouth of the Dnieper River to Kyiv at the level of $3.65 \mathrm{~m}$. Today, in some sections of this route, the depth is $2.9 \mathrm{~m}$. Therefore, today all agreements on the transit of goods from Belarus, the Baltic states to the ports of Odesa, Mykolaiv, and Ochakiv are impossible without dredging. This situation leads to the fact that the workload of 
ships does not exceed 65\% [33]. Currently, the river fleet began to be restored. One of the largest national agricultural producers is JV Nibulon LLC. This company plans to restore the Dnieper transport hub. Since 2009, JV Nibulon LLC has built 24 tugs and pushers, 48 barges, etc. The company's fleet includes 85 vessels with a total load capacity of more than 195 thousand tons [35]. It can transport agricultural products by such rivers as Southern Bug, Dnieper, Danube, etc., and in the coastal zone of the Black Sea. In addition, JV Nibulon LLC builds elevators and river terminals. Restoring river navigation will allow agricultural producers of Dnipropetrovsk, Zaporizhzhya, Kyiv, Poltava, and Cherkasy regions to export their products on more favorable terms with lower transport costs.

National costs on water transport infrastructure are relatively cheap. The investment costs for road transport (road construction and maintenance) are relatively low. Thus, it kind of transport is the most attractive (in terms of capital investment). However, infrastructural and external costs are EUR 40/(1000 tkm). Railway transport has the highest infrastructural and external costs of EUR $(68-71) /(1000 \mathrm{tkm})$. Inland waterways transport is the most attractive. The same indicator for IWT is equal to EUR 24/(1000 tkm) [36]. Thus, if a country has waterways, it should pay attention to inland shipping. For comparison, infrastructure and external costs in the European Union are as follows, EUR/(1000 tkm): road transport-from 28 to 77; railway transport-from 41 to 211; IWT-from 19 to 38 [37,38].

IWT has low transport costs. Its average values vary from USD $0.011 / \mathrm{tkm}$ to USD $0.027 / \mathrm{tkm}$. The same indicator for road transport is around USD $0.24 / \mathrm{tkm}$. Railways are between them, and their average transport costs are from USD $0.015 / \mathrm{tkm}$ to USD $0.018 / \mathrm{tkm}$ [36]. In the European Union, transport costs have the same trend. For road freight, this indicator ranges from EUR $0.0572 / \mathrm{tkm}$ to EUR $0.142 / \mathrm{tkm}$. It depends on load capacity and distance of transportation. Railway transport has a wider range: from EUR $0.02882 / \mathrm{tkm}$ to EUR $0.164 / \mathrm{tkm}$. As to inland shipping, the unit of transport costs depend on the distance of transportation, the vessel draft, and the type of return voyage (empty return or loaded return). For empty return voyage, transport costs are within the range from EUR $0.0241 / \mathrm{tkm}$ to EUR $0.0515 / \mathrm{tkm}$. For loaded return voyage, this indicator decreases and ranges from EUR $0.0167 / \mathrm{tkm}$ to EUR 0.0344/tkm [10].

\subsection{Energy Efficiency: Possible Minimum Value}

Supply chains of agricultural products comprise road transport, IWT, and maritime transport. Road transport delivers products from farmers to river terminals or elevators. Its distances of haulage are relatively short. In many cases, they do not exceed $50 \mathrm{~km}$ [39]. IWT supplies seaports. Its distances can be up to some hundred kilometers. Further, marine ships deliver agricultural products to end consumers. In this study, we analyze only IWT.

Transportation increases the costs of agricultural products and energy consumption due to the additional fuel consumption. Some characteristics of trucks are given in Table $3[40,41]$. The fuel economy depends on the truck make, trailers, cargo class, condition of roads, load factor, driver qualifications, etc. This indicator varies from 0.011 to $0.025 \mathrm{l} / \mathrm{tkm}$. Traction efficiency or cargo carried to a rated power ratio is calculated by Formula (3).

To reduce energy intensity, both organizational and technical measures can be applied. Organization measures include the use of road trains (reduction of fuel consumption by $20 \ldots 25 \%$ ), maintaining the proper technical condition of equipment, training of drivers, etc. Technical measures should include, first of all, the use of modern commercial vehicles. Adoption of relevant state standards will also contribute to this. Thus, in the United States, these measures have reduced the cost of road transportation per unit of mileage [42].

IWT uses dry cargo vessels, tankers, barges, tugs, etc. Barges with a carrying capacity of up to 9.2 thousand tons are used to transport goods by rivers. They can be combined into trains carrying up to 40 thousand tons of cargo. Pusher tugs are used to move them. Their main characteristics are given in Table 4 [43-45]. 
Table 3. Characteristics of selected trucks (road grain carriers).

\begin{tabular}{lccccc}
\hline \multicolumn{1}{c}{ Make } & $\begin{array}{c}\text { Engine Rated } \\
\text { Power, } \mathbf{k W}\end{array}$ & $\begin{array}{c}\text { Load } \\
\text { Capacity, } \mathbf{t}\end{array}$ & $\begin{array}{c}\text { Cargo Carried to a } \\
\text { Rated Power } \\
\text { Ratio, t/kW }\end{array}$ & $\begin{array}{c}\text { Fuel Economy, } \\
\text { L/100 } \mathbf{~ k m}\end{array}$ & $\begin{array}{c}\text { Specific Fuel } \\
\text { Consumption, } \\
\text { L/(1000 tkm) }\end{array}$ \\
\hline HOWO ZZ3327N4347C & 246.96 & 30 & 0.121 & 36 & 12.00 \\
KamAZ 6520-10 & 374.85 & 20 & 0.080 & 39 & 19.50 \\
KamAZ 53229 & 235.20 & 14 & 0.085 & 36 & 25.71 \\
FORD 3535D & 176.40 & 22 & 0.079 & 32 & 14.55 \\
KrAZ 6230C4 & 220.50 & 18 & 0.100 & 35 & 19.44 \\
KraAZ 65055-073-02 & 242.55 & 18 & 0.074 & 37 & 18.33 \\
MAZ 5516A8-336 & 243.00 & 20 & 0.074 & 48 & 12.00 \\
HOWO ZZ3317N3867C1 & 294.00 & 40 & 0.068 & 55 & 11.00 \\
MAN TGX 33.480 & 275.63 & 50 & 0.145 & & 5 \\
BB-WW & & & & & \\
\hline
\end{tabular}

Table 4. Characteristics of river fleet.

\begin{tabular}{|c|c|c|c|c|}
\hline Type of Vessel & Project & $\begin{array}{l}\text { Rated Power on Main } \\
\text { Engines, kW }\end{array}$ & Cargo Capacity, $t$ & $\begin{array}{l}\text { Cargo Carried to a Rated Power } \\
\text { Ratio, } t / k W\end{array}$ \\
\hline \multirow{5}{*}{$\begin{array}{l}\text { Dry cargo } \\
\text { self-propelled vessels }\end{array}$} & RSD44 & 2400 & 5698 & 2.37 \\
\hline & RSD06 & 1470 & 4492 & 3.06 \\
\hline & RSD11 & 1766 & 4434 & 2.51 \\
\hline & RSD49 & 2400 & 4505 & 1.88 \\
\hline & RSD59 & 2400 & 5320 & 2.22 \\
\hline \multirow{7}{*}{ Pushers and Tugs } & 121 & 882.0 & 6000 & 6.80 \\
\hline & $\mathrm{T} 410$ & 367.5 & 3000 & 8.16 \\
\hline & 81340 & 110.0 & 1300 & 11.82 \\
\hline & 81200 & 544.0 & 8000 & 14.71 \\
\hline & P153 & 1100.0 & 15,000 & 13.64 \\
\hline & 947 & 1837.5 & 20,000 & 10.88 \\
\hline & 81170 & 441.0 & 5000 & 11.34 \\
\hline
\end{tabular}

Pushers with barges have the lowest theoretical energy consumption per freight tkm (Figure 6). We used our calculations and data from the International Energy Agency and the International Union of Railways [46]. We used Formula (2) to calculate the specific energy consumption.

Traction efficiency of IWT is higher compared to road transport (Tables 3 and 4) and railways. Electric trains have the traction efficiency within the range from 0.68 to 1.35 [47]. Specific energy consumption of IWT is lower compared to road transport (Figure 4). The use of barges (and, accordingly, pushers) with a capacity of more than 3 thousand tons reduces fuel consumption and the costs of waterway transportation.

\subsection{Actual Energy Efficiency}

In 2018, transport by sectors consumed energy, thousand ton of oil equivalent: road7267; railway-603; IWT-39 [32]. In the same year, freight transport operations were equal to, million tkm: road-65; railway-181.8; IWT-1.6 [48]. The actual specific energy consumptions were equal, $\mathrm{kJ} / \mathrm{tkm}$ : road-4673.2; railway-138.64; IWT-1018.9. To determine the above, Formula (1) is used. Actual specific energy consumptions of Ukrainian transport systems exceed theoretical values (Figure 6) and similar indicators for European countries (Figure 7) [10,49]. Ukrainian railway has better specific energy consumption compared to European Union countries. It is a result of the fact that it has a higher load factor. 


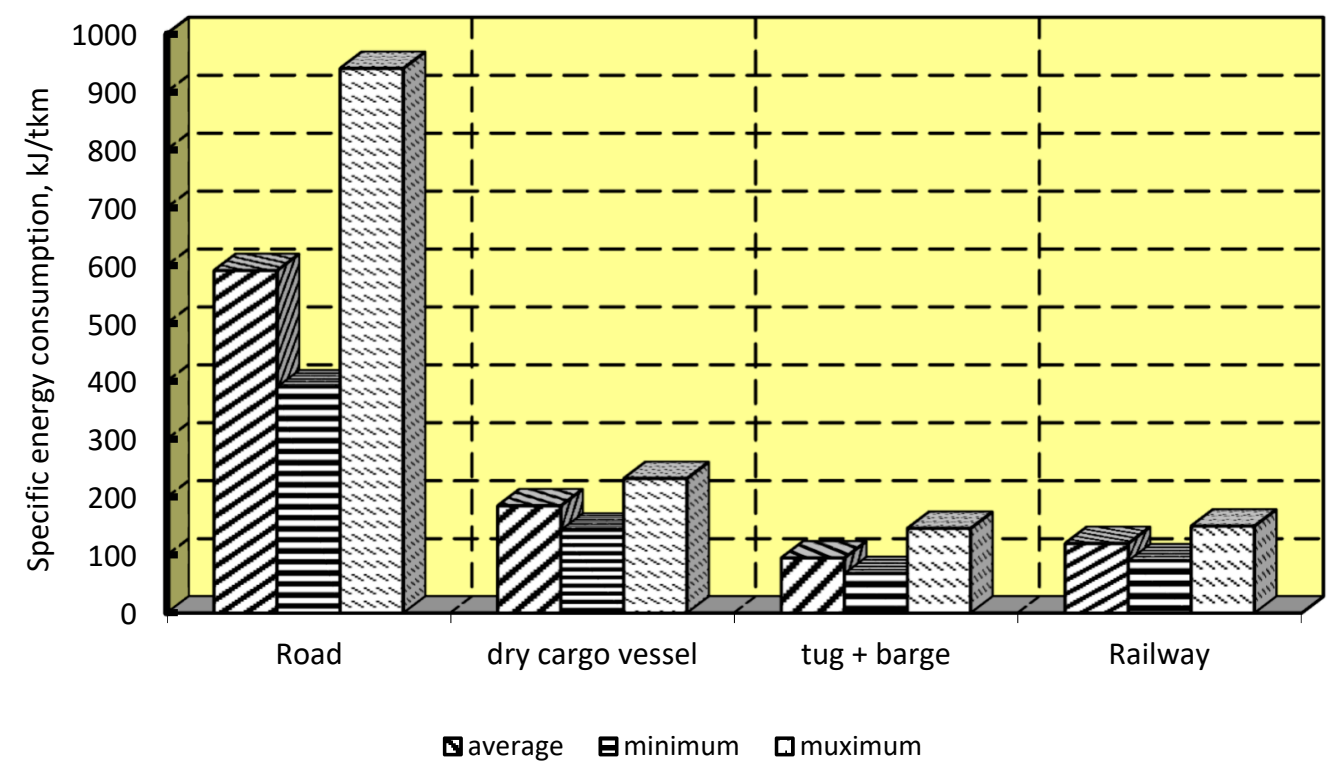

Figure 6. Specific energy consumption.

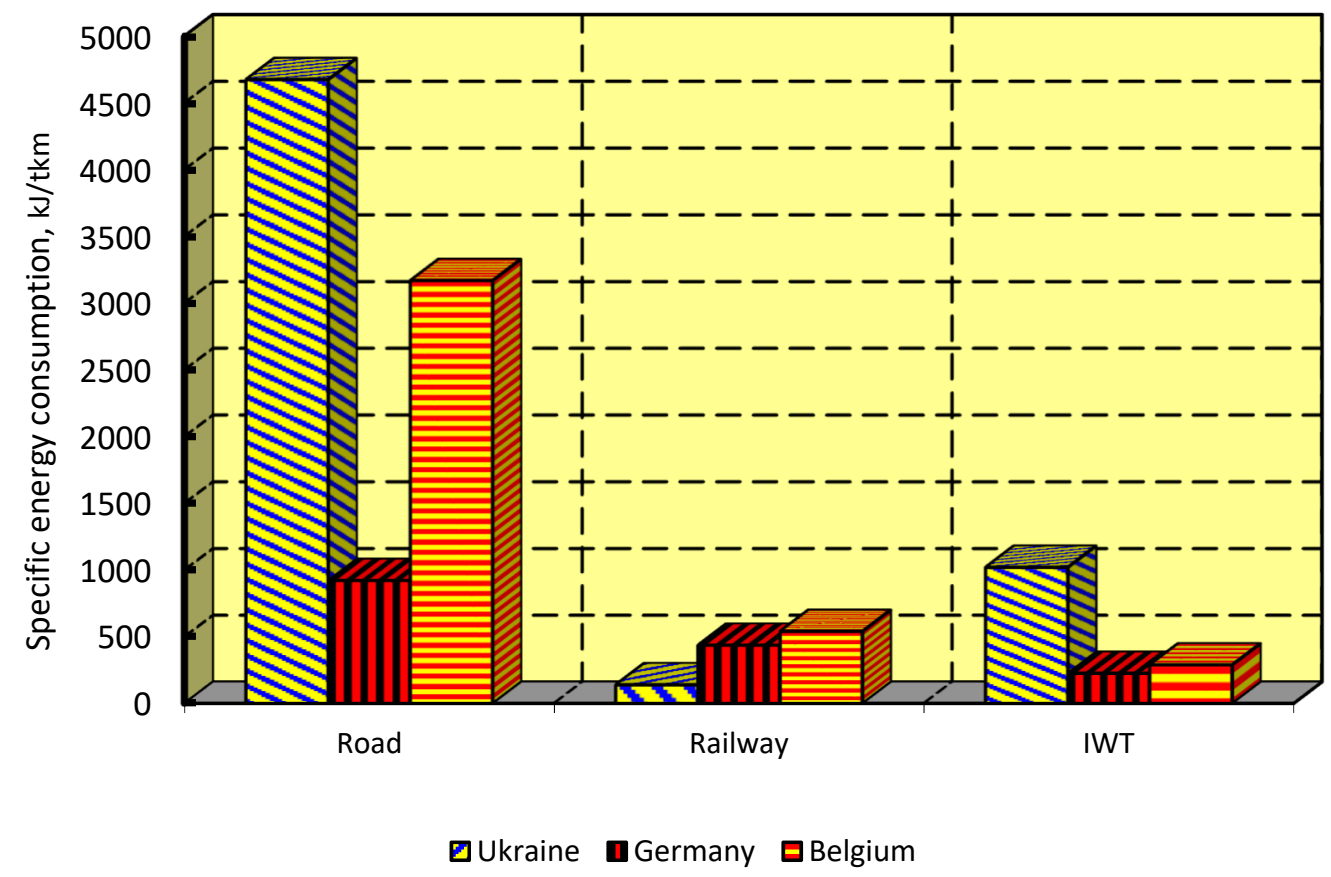

Figure 7. Actual specific energy consumption.

According to the data of the Royal Commission for Environmental Contamination Monitoring (Great Britain), the specific consumption of energy according to the transport mode is as follows, $\mathrm{kJ} / \mathrm{tkm}$ : road-2890; railway-677; river-423 [50]. As can be seen, inland waterway transport is 1.6 times more efficient than railway transportation and seven times than road transport. Its energy efficiency is closer to Ukrainian than Germany or Belgium. Radmilović and Dragović studied the traction efficiency of transportation means. They found the following limits, $\mathrm{t} / \mathrm{kW}$ : IWT—from 2.5 to 8 ; road—around 0.194; railway-from 0.523 to 1.7 . These values coincide with our results.

Energy-saving technologies are within three main domains: technical, operational, and transport management. They have different energy and economic efficiency (Table 5) [51]. 
Table 5. Possible innovations to improve energy performance of IWT.

\begin{tabular}{|c|c|c|c|c|}
\hline Area & Measure & Applicability & $\begin{array}{c}\text { Decrease in Energy } \\
\text { Consumption, } \%\end{array}$ & $\begin{array}{c}\text { Payback Period, } \\
\text { Years }\end{array}$ \\
\hline \multirow[t]{5}{*}{ Technical } & Father-son engine & New and retrofit & 10 & $7-8$ \\
\hline & Diesel-electric propulsion & New vessels & 10 & 10 \\
\hline & Electric propulsion & new & 10 & 15 \\
\hline & Optimized hull form & new & 10 & $3-4$ \\
\hline & Weight reduction by composite materials & New vessels & $5-15$ & $10-15$ \\
\hline \multirow[t]{3}{*}{ Operational } & Speed reduction & \multirow{6}{*}{ All vessels } & $10-30$ & $0.1-0.2$ \\
\hline & On-board information systems & & 10 & $<1$ \\
\hline & Optimal maintenance & & 5 & $<1$ \\
\hline \multirow[t]{3}{*}{$\begin{array}{l}\text { Transport } \\
\text { management }\end{array}$} & Reduction of empty trips & & high & \multirow{3}{*}{$\begin{array}{l}\text { No general } \\
\text { quantification } \\
\text { possible }\end{array}$} \\
\hline & Improving interface in seaports & & high & \\
\hline & $\begin{array}{l}\text { Electronic chart display and information } \\
\text { system for inland navigation }\end{array}$ & & high & \\
\hline
\end{tabular}

Ship power plants and their conditions cannot result in a fourfold increase in specific energy consumption. It means that reserves are within the following domains: the optimal deadweight and type of ships, the excluding empty voyages, the enhancing of load factor, etc. Ship-owners should optimize types of vessels and their dead weight. Barges may be a suitable type of vessel in national conditions. Sippers and ship-owners are both interested in excluding empty trips. It allows shippers to cut transport costs and ship-owners to increase profit. It is quite natural that, in this case, the energy consumption for cargo transportation is reduced. The enhancing of load factor is a function of the following: deadweight, type of vessel, waterway depth, and logistics. Dredging of waterways is the responsibility of authorities and businesses. Appropriate ships and logistics are the responsibility of shippers and ship-owners.

Shipping companies are looking for more energy-effective and cost-effective solutions for navigations [52-54]. The e-Navigation concept may be a solution. This concept has been developed by the International Maritime Organization (IMO) and the International Association of Marine Aids to Navigation and Lighthouse Authorities (IALA) [55]. It helps to ensure the efficiency and safety of inland waterway traffic [56,57].

\section{Conclusions}

The novelty of this study is within four domains. One important result is the estimation of the export potential of regions located in the Dnieper Basin. Since 2000, there has been a significant increase in agricultural production and its export. The share of these regions ranges from $37.57 \%$ to $50.92 \%$. Further, IWT is suitable to transport agricultural products to seaports.

The second result is that the possible minimum energy consumption has been determined. IWT has better traction efficiency (from 1.88 to $11.82 \mathrm{t} / \mathrm{kW}$ ) compared to road transport (from 0.07 to $0.145 \mathrm{t} / \mathrm{kW}$ ) and railway transport (from 0.68 to $1.35 \mathrm{t} / \mathrm{kW}$ ). The average specific fuel consumption of barges has the best value (around $100 \mathrm{~kJ} / \mathrm{tkm}$ ). Dry cargo ships are inferior to the railway.

The third contribution is the determining of actual energy consumption. The average specific energy consumption of IWT is between railway and road transport. It exceeds the specific energy consumption of European countries. Inland waterways transport is currently less energy efficient than railway one. Its actual specific energy consumption is five times higher than the theoretically possible value and four times higher compared to European Union's countries. Therefore, IWT has significant reserves for its development.

The fourth result is an analysis of possible energy-saving measures. First of all, reserves are within transport management. Its optimization should be used to improve the energy efficiency of IWT. The primary objectives are minimization of empty return voyages, 
downtime, and full use of the carrying capacity. The results obtained will allow authorities and shipping companies of any country to make reasonable decisions for its development.

Further research is planned to improve the results obtained. We will proceed to elaborate on problems of transport management as an energy-saving tool. Collecting data from IWT operators is part of the above aim. Moreover, road and maritime transport will be added to the methodology for an energy assessment of a whole product supply chain.

Author Contributions: Conceptualization, V.H.; methodology, V.H. and V.N.; software, O.B.; validation, V.H.; formal analysis, V.H. and V.N.; investigation, O.B.; resources, O.B.; data curation, V.N.; writing-original draft preparation, V.H. and V.N.; writing-review and editing, O.B. and V.N.; visualization, O.B.; supervision, V.H. and V.N.; project administration, O.B.; funding acquisition, O.B. All authors have read and agreed to the published version of the manuscript.

Funding: This study was carried out as part of the project "Belt and Road Initiative Institute for ChineseEuropean Studies" and was funded by the Guangdong University of Petrochemical Technology.

Institutional Review Board Statement: Not applicable.

Informed Consent Statement: Informed consent was obtained from all subjects involved in the study.

Data Availability Statement: Data sharing not applicable.

Acknowledgments: The authors would like to thank all the quality professionals who helped the research.

Conflicts of Interest: The authors declare no conflict of interest.

\section{References}

1. About the Grain of Ukraine Program. Available online: https://zakon.rada.gov.ua/rada/show/v0121244-98\#Text (accessed on 12 May 2021).

2. The Grain of Ukraine Program-2015. DIA: Kyiv, Ukraine, 2011; 48p. Available online: http://www.naas.gov.ua/content/zerno. doc (accessed on 15 May 2021).

3. Crop Production of Ukraine 2019. Statistical Yearbook. Kyiv, Ukraine. 2020. Available online: http://www.ukrstat.gov.ua/druk/ publicat/kat_u/2020/zb/04/zb_rosl_2019.pdf (accessed on 15 May 2021).

4. Agriculture of Ukraine. Statistical Yearbook. Kyiv, Ukraine. 2020. Available online: http://www.ukrstat.gov.ua/druk/publicat/ kat_u/2019/zb/09/Zb_sg_2018\%20.pdf (accessed on 15 May 2021).

5. Wang, Y.; Meng, Q.; Kuang, H. Intercontinental liner shipping service design. Transp. Sci. 2019, 53, 344-364. [CrossRef]

6. Qi, J.; Zheng, J.; Yang, L.; Yao, F. Impact analysis of different container arrival patterns on ship scheduling in liner shipping. Marit. Policy Manag. 2021, 48, 331-353. [CrossRef]

7. Dulebenets, M.A. A comprehensive multi-objective optimization model for the vessel scheduling problem in liner shipping. Int. J. Prod. Econ. 2018, 196, 293-318. [CrossRef]

8. Wang, Y.; Wang, S. Deploying, scheduling, and sequencing heterogeneous vessels in a liner container shipping route. Transp. Res. Part E Logist. Transp. Rev. 2021, 151, 102365. [CrossRef]

9. Pasha, J.; Dulebenets, M.A.; Fathollahi-Fard, A.M.; Tian, G.; Lau, Y.Y.; Singh, P.; Liang, B. An integrated optimization method for tactical-level planning in liner shipping with heterogeneous ship fleet and environmental considerations. Adv. Eng. Inform. 2021, 48, 101299. [CrossRef]

10. Federal German Water and Shipping Administration. Economical and Ecological Comparison of Transport Modes: Road, Railways, Inland Waterways. Summary of Findings. 2007. Available online: http://www.ebu-uenf.org/fileupload/SummaryStudy_ engl.pdf (accessed on 17 June 2021).

11. Galierikova, A.; Sosedova, J. Environmental aspects of transport in the context of development of inland navigation. Ekol. Bratisl. 2016, 35, 279-288. [CrossRef]

12. Sihn, W.; Pascher, H.; Ott, K.; Stein, S.; Schumacher, A.; Mascolo, G. A Green and Economic Future of Inland Waterway Shipping. Procedia CIRP 2015, 29, 317-322. [CrossRef]

13. Beleya, P.; Raman, G.; Chelliah, M.K.; Nodeson, S. Sustainability and green practices at Malaysian seaports: Contributors to the core competitiveness. J. Bus. Manag. Econ. 2015, 3, 23-27. [CrossRef]

14. Roadmap to a Single European Transport Area-Towards a Competitive and Resource Efficient Transport System. White Paper. 2011. Available online: https:/ / ec.europa.eu/transport/themes/strategies/2011_white_paper_en (accessed on 23 May 2021).

15. Biswas, A. Inland waterways for transportation of agricultural, industrial and energy products. Int. J. Water Resour. Dev. 1987, 3, 9-22. [CrossRef]

16. Ivanchenko, A.A.; Petrov, A.P.; Zhyvlyuk, G.E. Energy efficiency of ships and regulation of greenhouse gas emissions. Vestn. Gos. Univ. Morskogo Rechn. Flot. Im. Admirala SO Makarova 2015, 3, 103-112. [CrossRef] 
17. Erofeev, V.; Erofeeva, E. Practice and problems of estimating the energy efficiency of water transport infrastructure. Vestn. Gos. Univ. Morskogo Rechn. Flot. Im. Admirala SO Makarova 2014, 6, 143-154. [CrossRef]

18. Furfari, S. Energy efficiency of engines and appliances for transport on land, water, and in air. Ambio 2016, 45 (Suppl. S1), 63-68. [CrossRef]

19. Goncharuk, A.G.; Havrysh, V.I.; Nitsenko, V.S. National features for alternative motor fuels market. Int. J. Energy Technol. Policy 2018, 14, 226-249. [CrossRef]

20. Kalinichenko, A.; Havrysh, V.; Atamanyuk, I. The Acceptable Alternative Vehicle Fuel Price. Energies 2019, 12, 3889. [CrossRef]

21. Bazaluk, O.; Havrysh, V.; Nitsenko, V.; Baležentis, T.; Streimikiene, D.; Tarkhanova, E.A. Assessment of Green Methanol Production Potential and Related Economic and Environmental Benefits: The Case of China. Energies 2020, 13, 3113. [CrossRef]

22. Havrysh, V.; Kalinichenko, A.; Mentel, G.; Mentel, U.; Vasbieva, D.G. Husk Energy Supply Systems for Sunflower Oil Mills. Energies 2020, 13, 361. [CrossRef]

23. Song, M.; Wu, N.; Wu, K. Energy Consumption and Energy Efficiency of the Transportation Sector in Shanghai. Sustainability 2014, 6, 702-717. [CrossRef]

24. van Lier, T.; Macharis, C. Assessing the environmental impact of inland waterway transport using a life-cycle assessment approach: The case of Flanders. Res. Transp. Bus. Manag. 2014, 12, 29-40. [CrossRef]

25. Jonkeren, O.; Francke, J.; Visser, J. A shift-share based tool for assessing the contribution of a modal shift to the decarbonisation of inland freight transport. Eur. Transp. Res. Rev. 2019, 11, 8. [CrossRef]

26. Caris, A.; Limbourg, S.; Macharis, C.; Van Lier, T.; Cools, M. Integration of Inland Waterway Transport in the Intermodal Supply Chain: A Taxonomy of Research Challenges. J. Transp. Geogr. 2014, 41, 126-136. [CrossRef]

27. Egorov, A. Freight trains for the Dnieper, Black Sea and Danube. Shipbuild. Ship Repair 2019, 23, 3. Available online: http: / / sudostroy.com/gruzovye-sostavy-dlja-dnepra-chernogo-morja-i-dunaja/ (accessed on 12 June 2021).

28. Pidlisnyi, P. Inland water transport: History, problems, directions of development. Economist 2016, 1, 10-20.

29. Yin, R.K. Case Study Research: Design and Methods, 3rd ed.; Applied Social Research Methods Series; SAGE Publications: Thousand Oaks, CA, USA; London, UK; New Delhi, India, 2003; Volume 5, 181p.

30. Ukraine Becomes World's Second Grain Exporter. Available online: https://www.ukrinform.net/rubric-economy/3176698ukraine-becomes-worlds-second-largest-grain-exporter.html (accessed on 14 June 2021).

31. TOP 10 Importing Countries of Ukrainian Grain in 2020. Available online: https://latifundist.com/en/rating/top-10-stranimporterov-ukrainskogo-zerna-v-2020-godu (accessed on 15 June 2021).

32. Transport of Ukraine. Statistical Yearbook 2019. Available online: http://www.ukrstat.gov.ua/druk/publicat/kat_u/2020/zb/ 10/zb_trans_19.pdf (accessed on 17 June 2021).

33. Development of River Logistics is Vital for Ukraine. Available online: http://uga.ua/meanings/razvitie-rechnoj-logistikizhiznenno-neobhodimo-ukraine-aleksej-vadaturskij/ (accessed on 5 September 2021).

34. Statistical Yearbook of Ukraine for 2018. Available online: http://ukrstat.gov.ua/druk/publicat/kat_u/2019/zb/11/zb_ yearbook_2018.pdf (accessed on 18 June 2021).

35. Shipping company JV “NIBULON”. Available online: https://www.nibulon.com/data/filii/sudnoplavna-kompaniya.html (accessed on 19 June 2021).

36. Transport balance of Ukraine 2014/2015. Available online: https:/ / toplead.com.ua/ru/get_file/id/transportbalance-of-ukraine pdf (accessed on 21 June 2021).

37. Overview of Transport Infrastructure Expenditures and Costs, January 2019. Available online: https://cedelft.eu/wp-content/ uploads/sites/2/2021/03/CE_Delft_4K83_Overview_transport_infrastructure_expenditures_costs_Final.pdf (accessed on 5 September 2021).

38. Hofbauer, F.; Putz, L.M. External Costs in Inland Waterway Transport: An Analysis of External Cost Categories and Calculation Methods. Sustainability 2020, 12, 5874. [CrossRef]

39. Feofilov, S. Efficient Logistics: Developing Trade and Increasing Food Security. Available online: http://www.eurasiancommission. org/ru/act/prom_i_agroprom/dep_agroprom/SiteAssets/\%D0\%A3\%D0\%BA\%D1\%80\%D0\%90\%D0\%B3\%D1\%80\%D0\%BE\%

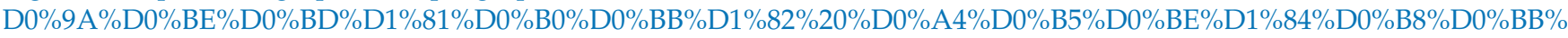
D0\%BE\%D0\%B2.pdf (accessed on 5 September 2021).

40. Grain Carriers HOWO. Available online: http:/ / www.npf-midas.com.ua/zernovoz.php (accessed on 24 June 2021).

41. Grain Carriers MAN TGX 33.480 BB-WW. Available online: https:/ / man-unikom.ru/zernovoz.php (accessed on 1 July 2021).

42. Energy Information Administration; Office of Integrated Analyses and Forecasting; US Department of Energy. Annual Energy Outlook 2007 with Projections to 2030; DOE/EIA-0383; Washington, DC, USA, February 2006. Available online: http:/ /large. stanford.edu/courses/2012/ph240/park1/docs/0383-2007.pdf (accessed on 5 July 2021).

43. Egorov, G.; Chaban, A.; Avtukhov, N. Dry-cargo vessels of mixed navigation "Volgo-Don Max" of the class "Chelsea". Marit. Mark. 2009, 2. Available online: https:/ / www.maritimemarket.ru/article.phtml?id=1022 (accessed on 6 July 2021).

44. Maritime Engineering Bureau. Available online: http://meb.com.ua/dry/RSD49.html (accessed on 8 July 2021).

45. Marine Transport. Available online: https:/ fleetphoto.ru/projects/177/?lang=ru (accessed on 8 July 2021).

46. International Energy Agency; the International Union of Railways. Railway Handbook 2017. International Energy Agency: Paris, France, 2017; 120p. Available online: https://uic.org/IMG/pdf/handbook_iea-uic_2017_web3.pdf (accessed on 14 July 2021). 
47. Cargo Electric LOCOMOTIVES. Available online: http:/ / www.rzd-expo.ru/gallery/list.php?PAGE_NAME=section\&SECTION_ ID=181 (accessed on 16 July 2021).

48. Fuel and Energy Resources of Ukraine. Statistical Publication. Kyiv, Ukraine. 2020. Available online: http://www.ukrstat.gov. ua/druk/publicat/kat_u/2020/zb/12/Zb_per.pdf (accessed on 16 July 2021).

49. Merchan, A.L.; Belboom, S.; Léonard, A. Life Cycle Assessment of freight transport in Belgium. In Proceedings of the BIVECGIBET Transport Research Days, Liège, Belgium, 18-19 May 2017. Available online: https://orbi.uliege.be/handle/2268/213283 (accessed on 17 July 2021).

50. Radmilović, Z.; Dragović, B. The inland navigation in Europe: Basic facts, advantages and disadvantages. J. Marit. Res. 2007, 4, 31-46. Available online: https:/ / dialnet.unirioja.es / servlet/articulo?codigo=2505120 (accessed on 9 September 2021).

51. Verberght, E. Innovative Inland Navigation. Report 2019; Department of Transport and Regional Economic, University of Antwerp: Antwerp, Belgium, 2019. Available online: https:/ / www.etf-europe.org/wp-content/uploads/2019/05/INN-IN-final-report.pdf (accessed on 5 September 2021).

52. Nitsenko, V.; Kotenko, S.; Hanzhurenko, I.; Ingram, K.L. Determination of Weight Coefficients for Stochastic and Fuzzy Risks for Multimodal Transportation. J. Phys. 2020, 1529, 032007. [CrossRef]

53. Kotenko, S.; Nitsenko, V.; Hanzhurenko, I.; Havrysh, V. The Mathematical Modeling Stages of Combining the Carriage of Goods for Indefinite, Fuzzy and Stochastic Parameters. Int. J. Integr. Eng. 2020, 12, 173-180. [CrossRef]

54. Bazaluk, O.; Kotenko, S.; Nitsenko, V. Entropy as an Objective Function of Optimization Multimodal Transportations. Entropy 2021, 23, 946. [CrossRef] [PubMed]

55. Weintrit, A. Initial Description of Pilotage and Tug Services in the Context of e-Navigation. J. Mar. Sci. Eng. 2020, 8, 116. [CrossRef]

56. Formela, K.; Neumann, T.; Weintrit, A. Overview of Definitions of Maritime Safety, Safety at Sea, Navigational Safety and Safety in General. TransNav Int. J. Mar. Navig. Saf. Sea Transp. 2019, 13, 285-290. [CrossRef]

57. Jonas, M.; Oltmann, J.-H. IMO e-Navigation Implementation Strategy-Challenge for Data Modelling. TransNav Int. J. Mar. Navig. Saf. Sea Transp. 2013, 7, 45-49. [CrossRef] 